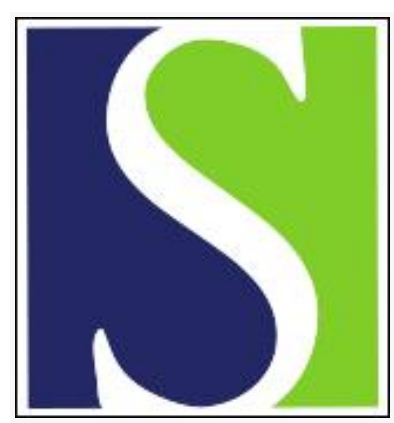

Scand J Work Environ Health 1986;12(1):55-60

https://doi.org/10.5271/sjweh.2174

Issue date: Feb 1986

Estimates of the proportion of bladder cancers attributable to occupation.

by Vineis $P$, Simonato $L$

This article in PubMed: www.ncbi.nlm.nih.gov/pubmed/3961442

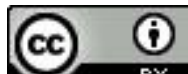




\title{
Estimates of the proportion of bladder cancers attributable to occupation
}

\author{
by Paolo Vineis, MD, ${ }^{1}$ Lorenzo Simonato, $M D^{2}$
}

\begin{abstract}
VINEIS P, SIMONATO L. Estimates of the proportion of bladder cancers attributable to occupation. Scand J Work Environ Health 12 (1986) 55-60. In order to estimate the proportion of bladder cancers attributable to occupation in different countries, three criteria were defined, each with a different degree of strictness, for the inclusion of job titles or industrial activities in the estimates. Such criteria were applied to the available case-referent studies, the range for the less severe criterion estimates being $0-19 \%$ and that of the strictest being $1-19 \%$. The variability was greater among the studies than among the criteria of inclusion of occupations; therefore the study design and time- and place-specificity of exposures play an important role in the magnitude of such estimates.
\end{abstract}

Key terms: attributable risk, case-referent studies.

From several case-referent (control) studies undertaken in industrialized countries, it has been estimated that the proportion of bladder cancer cases attributable to occupational exposure in the general male population ranges from $8-10 \%(10,25)$ to $20 \%(1,19)$. These studies used different designs and different methods in the collection and classification of occupational data; in addition, the criteria used for the estimation of attributable risks were not always fully reported.

The present paper reevaluates the relevant available literature using predefined and standardized criteria for the estimation of attributable risks. Job titles and/or industrial activities to be included in the estimates have been defined a priori on the basis of different (more or less stringent) criteria, which were subsequently applied to each of the available studies in the literature. A single overall estimate would not be informative, since attributable risks in the population are time- and place-specific (5); in particular, they depend on (i) the proportion of people employed in different jobs and (ii) the extent and intensity of the exposure to carcinogens in the relevant jobs.

\section{Materials and methods}

\section{Attributable risk}

The attributable risk in a population (ARp) is the epidemiologic measure representing the proportion of the cases of a given disease attributable to a given exposure in a population; it represents also the proportion of cases preventable by the elimination of that exposure.

${ }^{1}$ Unit of Cancer Epidemiology, Main Hospital and University of Turin, 7, Via Santena, I-10126 Turin, Italy.

2 Unit of Analytical Epidemiology, International Agency for Research on Cancer, 150 Cours Albert-Thomas, F-69372 Lyon cedex 08, France.

Reprint requests to: Dr P Vineis, Unit of Cancer Epidemiology, Main Hospital and University of Turin, 7 Via Santena, I-10126 Turin, Italy.
In the estimation of attributable risk in a population we have used the formula suggested by Miettinen for case-referent studies (12): $A R p=(R R-1) / R R \times$ $\mathrm{p}_{\mathrm{ec}}$, where $\mathrm{RR}=$ relative risk and $\mathrm{p}_{\mathrm{ec}}=$ proportion of exposed cases. It should be stressed that, rigorously speaking, the use of such a formulation is adequate for population-based case-referent (control) studies only, in which the cases are representative of all cases occurring in a definite population and the referents are a representative sample of the same population.

\section{Criteria for the inclusion of occupations}

In strict terms, the exposures at issue for our purpose should be represented by occupations causally associated with bladder cancer. According to recent reviews $(5,11,21)$ these are occupations in the rubber, dyestuff, and gas industries. However, an attributable risk computed in this way for a population would probably represent an underestimation due to the exclusion of a number of occupational exposures involving a real but not yet clearly recognized risk for cancer of the bladder. We have therefore defined a priori the following three different criteria for the inclusion of occupational categories reported by available investigations:

I. Occupational categories showing a statistically significant association in at least one study, with relative risks greater than 1.0 in all the informative studies (ie, those providing absolute numbers of cases and referents for those occupational categories).

II. Occupational categories showing a statistically significant association in at least one study with relative risks greater than one in all the informative studies with at least $5 \%$ of the referents exposed.

III. Occupational categories showing a statistically significant association in at least two studies with 
relative risks greater than 1.0 in all the informative studies with at least $5 \%$ of the referents exposed. Five percent of the referents exposed was introduced as a threshold because it corresponds to an acceptable statistical power (see table 4 and the Discussion).

Rubber, dyestuff, and gas workers were included in each estimate. Jobs and/or industrial activities falling into the criteria were identified from the case-referent studies included in the survey. All of them provided age-adjusted estimates of the relative risks with the exception of Wynder et al (27) and Tola et al (23). Doseresponse relationships and biological plausibility, which would represent other criteria for causality assessment in addition to the consistency and statistical significance of the associations, could not be considered due to the unavailability of information.

\section{Selection of the studies}

Only case-referent studies allowed for the estimation of attributable risks in the population. Cohort studies might be used in particular cases, eg, when a crosssectional survey on the prevalence of the exposure at issue is available or the study population is a sample of the general population; however, these conditions do not apply to any study we reviewed. All published case-referent studies reporting information on occupations and absolute numbers of cases and referents were taken into account. The following were subsequently excluded: (i) two papers giving information on a few chemical exposures but not on job titles or industrial activities $(24,26)$; (ii) those reporting data only for a very. limited list of occupations (less than 10) $(3,7,9,16,18)$; (iii) those aiming at hypothesis generation, such as routine mortality statistics by oc-

Table 1. Design of the case-referent studies included in the estimate of attributable risk within a population.

\begin{tabular}{ll}
\hline Study & Population \\
\hline $\begin{array}{l}\text { Wynder et al, } \\
1963 \text { (27) }\end{array}$ & $\begin{array}{l}\text { Males: } 300 \\
\text { cases and } 300 \\
\text { referents }\end{array}$ \\
$\begin{array}{ll}\text { Anthony \& Thomas, } \\
1970 \text { (1) }\end{array}$ & $\begin{array}{l}\text { Males: } 812 \text { cases } \\
\text { and } 652 \text { referents }\end{array}$
\end{tabular}

Cole et al, $1972(4)$

Males: 356 cases and 374 referents

Howe et al, $1980(10)$

Males 480 cases and 480 referents

Tola et al, 1980 (23)

Males: 134 cases and 134 referents

Cartwright, 1982 (2)

Males: 743 cases and 993 referents

Silverman et al, 1983 (20)

Males: 303 cases and 296 referents

Schoenberg et al, 1984 (19)

Males: 658 cases and 1258 referents

Vineis \& Magnani, 1985 (25)

\section{Design}

Hospital-based study: sex- and age-matched referents; papillomas ex cluded; cancers of the respiratory system and the upper alimentary tract and myocardial infarction excluded from the referents; interview on the whole occupational history; control of confounding by age (matching)

Hospital-based study: cases recruited in 1958-1967, 340 surgical and 312 other cancer referents (excluding genitourinary) recruited in 1955-1958; interview on the whole occupational history; matching by age, residence, and smoking habits

Population-based study: cases randomly selected among all (491) incident cases occurring in 1967-1968 in 87 cities of the Boston area (20-89 years of age); referents a random sample of 20 - to 89 -year-old residents, matched for sex and year of birth; $140 / 470$ case and 78/500 referent interviews obtained from spouse or next-of-kin (men and women); interview on the whole occupational history; control of confounding by age and smoking habits

Population-based study: eligible cases were all patients with newly diagnosed bladder cancer in three Canadian provinces $(1974-1976)(77 \%$ interviewed); referents matched for sex, age, and neighborhood (refusals were 20,4 , and $0 \%$ in the three provinces; refusing referents were substituted); male cases had higher education and income than the referents interview on the whole occupational history; control of confounding by age (matching) and smoking

Mixed design: originally eligible cases were all those $(\mathrm{N}=274)$ reported to the Finnish Cancer Registry in 1975-1976 for five Finnish provinces postal questionnaires sent to 269 cases and 271 sex- and age-matched hospital referents or their relatives; responses were $80 \%$ (cases) and $81 \%$ (referents); the whole occupational history collected; control of confounding by age (matching)

Mixed design: incident and prevalent cases in West Yorkshire; sex-and age-matched hospital referents (25\% arterial disease; $60 \%$ accident, minor or cold surgery; $10 \%$ chest conditions); interview on the whole occupational history; control of confounding by age and health district (matching)

Population-based study: all histologically confirmed incident cases $(81 \%$ interviewed); referents randomly selected by digit dialing (age $21-64$ years) or from lists of the Health Care Administration (age $\geq 65$ years) (respondents $84-89 \%$ ); interview on all jobs lasting at least six months; control of confounding by age, smoking, and other high-risk industries

Population-based study: incident cases with histologically confirmed carcinoma (90\% interviewed); selection of referents as in Silverman et al (20) ( $87 \%$ interviewed); interview on all jobs lasting at least six months; control of confounding by age, smoking, and five other variables

Hospital-based study: incident + prevalent cases; referents were 225 persons with benign urological conditions and 371 with mostly benign surgical diseases; refusals were 11 cases and 12 referents; interview on all jobs lasting at least six months, control of confounding by age and smoking 
Table 2. Absolute numbers of cases/referents (age-adjusted relative risks in parentheses) for the job titles or iridustrial activities associated with at least one statistically significant increased relative risk for bladder cancer in the case-referent studies reviewed (men only). ${ }^{\text {a }}$

\begin{tabular}{|c|c|c|c|c|c|c|c|c|c|}
\hline $\begin{array}{l}\text { Job title or } \\
\text { industrial } \\
\text { activity }\end{array}$ & $\begin{array}{l}\text { Wynder et al } \\
(27) \\
{[300 / 300]}\end{array}$ & $\begin{array}{l}\text { Anthony \& } \\
\text { Thomas (1) } \\
\text { [812/652] }\end{array}$ & $\begin{array}{l}\text { Cole et al } \\
(4)^{\mathrm{b}} \\
{[345 / 345]^{\mathrm{c}}}\end{array}$ & $\begin{array}{l}\text { Howe et al } \\
(10)^{d} \\
{[480 / 480]}\end{array}$ & $\begin{array}{l}\text { Tola et al. } \\
(23) \\
{[134 / 134]}\end{array}$ & $\begin{array}{l}\text { Cartwright } \\
(12) \\
{[743 / 993]}\end{array}$ & $\begin{array}{l}\text { Silverman } \\
\text { et al }(20) \\
{[303 / 296]}\end{array}$ & $\begin{array}{l}\text { Schoenberg } \\
\text { et al (19) } \\
\text { [658/1258] }\end{array}$ & $\begin{array}{l}\text { Vineis \& } \\
\text { Magnani (25) } \\
\text { [512/596] }\end{array}$ \\
\hline $\begin{array}{l}\text { Leather/tanning } \\
\text { Textife }\end{array}$ & $\begin{array}{l}3 / 0 \\
8 / 3 \\
\text { Tailors } 4 / 1\end{array}$ & $\begin{array}{l}9 / 14(<1.0) \\
50 / 19(2.2)^{\mathrm{b}}\end{array}$ & $\begin{array}{l}65 / 34(2.2)^{\mathbf{e}} \\
\text { Tailor, presser } \\
8 / 7(1.1)^{f}\end{array}$ & $\begin{array}{l}5 / 4(1.2) \\
\text { Dyeing of } \\
\text { cloth } \\
2 / 1(2.0) \\
3 / 2(1.5)\end{array}$ & $\begin{array}{l}2 / 0 \\
1 / 2\end{array}$ & $\begin{array}{l}8 / ?(1.2) \\
\text { Woollen } \\
\text { dyeing } 24 / ? \\
(1.3)\end{array}$ & $\begin{array}{l}4 / 8(0.5) \\
7 / 10(0.7)\end{array}$ & $\begin{array}{l}19 / 19(1.8) \\
12 / 31(0.6)\end{array}$ & $\begin{array}{l}11 / 3(3.8)^{e} \\
21 / 13(1.8)\end{array}$ \\
\hline Rubber & .. & $1 / 0$ & $46 / 32.5(1.6)^{e}$ & $5 / 1(5.0)$ & $1 / 0$ & .. & $\begin{array}{l}\text { Rubber } \\
\text { workers } 2 / 0\end{array}$ & $14 / 12(2.15)$ & $\begin{array}{l}14 / 14(1.2) \\
15 / 7(2.5)^{\mathrm{e}}\end{array}$ \\
\hline Dye manufacture & & $10 / 0(>8.1)^{e}$ & $\begin{array}{l}6 / 3.5(2.3) \\
14 / 15(1.3)\end{array}$ & & $1 / 1$ & $\begin{array}{l}65 / ?(3.5)^{\mathrm{e}} \\
18 / ?(3.1)^{\mathrm{e}}\end{array}$ & $50 / 45(1.1)$ & $20 / 38(0.9)$ & $14 / 2(8.8)^{e}$ \\
\hline Petroleum & $\begin{array}{l}3 / 2 \\
\ldots\end{array}$ & $\cdots$ & $79 / 79(1.2)$ & $\ddot{16 / 3}(5.3)^{\mathrm{e}}$ & $\begin{array}{l}111 \\
\ldots\end{array}$ & $\begin{array}{l}101 ?(0.1)^{\circ} \\
\ldots\end{array}$ & $6 / 1(6.0)$ & $13 / 19(1.3)$ & \\
\hline $\begin{array}{l}\text { Chemical workersg } \\
\text { (other or } \\
\text { unspecified) }\end{array}$ & . & $15 / 6(2.0)$ & $\begin{array}{l}\text { Organic } \\
13 / 9.5(1.4) \\
\text { Other } 17 / 20 \\
(1.0)\end{array}$ & $15 / 2(7.5)^{\mathrm{e}}$ & . & . & $5 / 13(0.4)$ & $\begin{array}{l}50 / 91(1.0) \\
\text { (including } \\
7 / 10 \text { paint } \\
\text { manufact) }\end{array}$ & $9 / 7(1.4)$ \\
\hline Painters ${ }^{h}$ & $12 / 10$ & $19 / 17(<1.0)$ & $23 / 25$ (1.2) & $\begin{array}{l}\text { Commercial } \\
24 / 20(1.0) \\
\text { Spray } 16 / 9 \\
(1.8)\end{array}$ & $3 / 3$ & . & $15 / 14(1.0)$ & $39 / 42(1.5)$ & $\begin{array}{l}7 / 4(2.0) \\
\text { (car painters) }\end{array}$ \\
\hline $\begin{array}{l}\text { Machinists, } \\
\text { engineers }\end{array}$ & $14 / 14$ & $24 / 7(2.8)^{e}$ & . & $19 / 7(2.7)^{e}$ & $5 / 1$ & $288 / ?(1.5)^{\mathrm{e}}$ & $13 / 10(1.3)^{i}$ & $\cdots$ & $\begin{array}{l}\text { Turners 9/3 } \\
(3.1) i\end{array}$ \\
\hline & & $\begin{array}{l}\text { (engineering } \\
\text { fitters and } \\
\text { engineers) }\end{array}$ & & & $\begin{array}{l}+ \text { turner, } \\
\text { filer } 2 / 1\end{array}$ & & $46 / 34(1.4)$ & & \\
\hline $\begin{array}{l}\text { Metal workers } \\
\text { (other or } \\
\text { unspecified) }\end{array}$ & $4 / 2$ & . & $26 / 31(0.8)^{1}$ & $6 / 0$ & $1 / 3$ & . & $\begin{array}{l}46 / 33(1.4)^{i} \\
3 / 1(3.0)^{i} \\
22 / 19(1.1)\end{array}$ & $65 / 99(1.1)$ & $40 / 40(1.3)$ \\
\hline Plumbers $^{n}$ & $6 / 3$ & . & .. & & $0 / 3$ & .. & .. & . & $\ldots$ \\
\hline Welding & . & . & & $17 / 6(2.8)^{e}$ & .. & . & $18 / 30(0.6)$ & . & . \\
\hline Sailors & . & . & $26 / 33(0.8)^{t}$ & & . & . & $6 / 16(0.4)^{e}$ & . & \\
\hline Railroad workers & . & . & . & $9 / 1(9.0)^{e}$ & . & . & $22 / 12(1.9)$ & $\ldots$ & $7 / 13(0.5)$ \\
\hline $\begin{array}{l}\text { Guards and } \\
\text { watchmen }\end{array}$ & . & . & .. & $16 / 4(4.0)^{e}$ & . & .. & $15 / 16(0.9)$ & . & . \\
\hline Nursery men & . & & .. & $11 / 2(5.5)^{\mathrm{e}}$ & .. & .. & & .. & .. \\
\hline Armed services & .. & $8 / 17(0.4)$ & & $82 / 45(1.8)^{e}$ & & ion & $29 / 32(0.9)$ & $\cdots$ & $\cdots$ \\
\hline Clerical workers & $\begin{array}{l}\cdots \\
\cdots \\
\cdots\end{array}$ & $39 / 30(1.1)$ & $\begin{array}{l}\text { Shipping } \\
33 / 23(1.4)^{\dagger} \\
\text { Postal 18/12 } \\
(1.5)^{\dagger} \\
\text { Other 19/15 } \\
(1.2)^{f}\end{array}$ & $16 / 7(2.3)$ & $13 / 18$ & $152 / ?(1.5)^{e}$ & $52 / 49(1.0)$ & . & . \\
\hline Truck drivers & $\begin{array}{l}1 / 1 \text { (coal truck } \\
\text { drivers) }\end{array}$ & K. & $\ldots$ & $\begin{array}{l}\text { Diesel and } \\
\text { traffic fumes } \\
11 / 4(2.8)\end{array}$ & .. & $\cdots$ & $42 / 18(2.5)^{\mathrm{e}}$ & $70 / 114(1.1)$ & $16 / 16(1.2)$ \\
\hline $\begin{array}{l}\text { Garage and/or gas } \\
\text { station workers } \\
\text { Barbers/hair- }\end{array}$ & - & . & $\cdots$ & . & . & $\cdots$ & $18 / 15(1.2)$ & $43 / 36(2.3)^{\mathrm{e}}$ & . \\
\hline $\begin{array}{l}\text { dressers } \\
\text { Food counter }\end{array}$ & $4 / 0$ & $6 / 1(4.9)$ & $4 / 7(0.4)^{\dagger}$ & $3 / 0$ & . & $4 / ?(0.9)$ & $3 / 2(1.5)$ & $12 / 17(1.3)$ & $9 / 11(0.9)$ \\
\hline workers/cooks & . & . & $32 / 21(1.55)^{\dagger}$ & . & . & . & $15 / 8(1.9)$ & $46 / 50(1.8)^{\mathrm{e}}$ & \\
\hline Butchers & $\ldots$ & . & . & . & .. & .. & .. & . & $10 / 4(2.9)^{e}$ \\
\hline
\end{tabular}

a Total number of cases/referents in brackets in the column heading for each study.

b Ever employed.

c 345 cases and 345.0 expected cases (expected values estimated from the reference group).

Discordant pairs.

e Statistically significant $(p<0.05)$.

' Out of 1241 occupations in 345 cases and 1241 occupations in 345 referents.

8 Unspecified or other than dyestuff and petroleum.

h Painters, metal workers, plumbers, and barbers/hairdressers were included because of several studies reporting a relative risk of $>1.0$, although none was statistically significant; they are not considered for inclusion in table 3 .

Expected numbers.

Start of employment before 1940 and duration of employment $>10$ years.

cupational categories $(13,17)$. All other published investigations were considered. One report (22) was not included because of difficulties in identifying the absolute numbers of exposed cases and referents. The report by Decoufle et al (8) on the Roswell Park Memorial Institute experience was not used because the absolute number of bladder cancers was not traced in the publication, and therefore the attributable risk could not be estimated for the population. Howe et al (10) reported only discordant pairs for each of the occupations listed with a possible underestimation of the attributable risk due to the exclusion of concordant pairs from the computation of the proportion of exposed cases. From Cole et al (4) only "ever employed" cases and referents were extracted. Only men have been considered in the review.

\section{Results}

Table 1 reports the study designs of the case-referent studies included in the review. All were based on personal interviews on the whole occupational history, 
Table 3. Estimate of the population attributable risks (ARp) for occupational exposure. The age-adjusted relative risks (RR) for each job within each study are presented with the percentage of exposed cases in parentheses.

\begin{tabular}{ccccccccc}
$\begin{array}{c}\text { Wynder } \\
\text { et al } \\
(27)^{\mathrm{a}}\end{array}$ & $\begin{array}{c}\text { Anthony } \\
\text { \& Thomas } \\
(1)\end{array}$ & $\begin{array}{c}\text { Cole } \\
\text { et al } \\
(4)^{\mathrm{b}}\end{array}$ & $\begin{array}{c}\text { Howe } \\
\text { et al } \\
(10)^{\mathrm{b}}\end{array}$ & $\begin{array}{c}\text { Tola } \\
\text { et al } \\
(23)^{\mathrm{a}}\end{array}$ & $\begin{array}{c}\text { Cartwright } \\
\text { (2) }\end{array}$ & $\begin{array}{c}\text { Silverman } \\
\text { et al } \\
(20)^{\mathrm{b}}\end{array}$ & $\begin{array}{c}\text { Schoenberg } \\
\text { et al } \\
(19)^{\mathrm{b}}\end{array}$ & $\begin{array}{c}\text { Vineis } \\
\text { \& Magnani } \\
(25)\end{array}$ \\
\hline
\end{tabular}

Criterion I (RR greater than 1.0 in all the informative studies + at least one study with statistically significant $R R)$

\begin{tabular}{|c|c|c|c|c|c|c|c|c|c|c|c|c|c|}
\hline Petroleum & - & - & & $1.2(22.9)$ & 5.3 & (3.3) & - & & - & 6.0 & (2.0) & $1.3(2.0)$ & - \\
\hline engineers & $1.0 \quad(4.7)$ & 2.8 & (3.0) & - & 2.7 & $(4.0)$ & 5.1 & $(3.7)$ & $1.5(38.8)$ & & (4.3) & - & 3.1 \\
\hline $\begin{array}{l}\text { Truck drivers } \\
\text { Garage and gas }\end{array}$ & $1.0 \quad(0.3)$ & - & & - & 2.8 & (2.3) & - & & - & & $\begin{array}{l}(15.2) \\
13.9)\end{array}$ & $1.1(10.6)$ & 1.2 \\
\hline station & - & - & & - & - & & - & & - & 1.2 & (5.9) & $2.3 \quad(6.5)$ & - \\
\hline $\begin{array}{l}\text { Food counter } \\
\text { workers \& cooks }\end{array}$ & - & - & & $1.55(2.6)$ & - & & - & & - & 1.9 & (4.9) & $1.8(7.0)$ & - \\
\hline Rubber ${ }^{c}$ & - & $\infty$ & $(0.1)$ & $1.6(13.3)$ & 5.0 & (1.0) & $\infty$ & $(0.7)$ & - & $\infty$ & $(0.7)$ & $2.15(2.1)$ & $\begin{array}{l}1.2 \\
2.5\end{array}$ \\
\hline $\begin{array}{l}\text { Dyestuffc } \\
\text { Gas workers }\end{array}$ & $\overline{-}$ & $\begin{array}{l}\infty \\
2.4\end{array}$ & $\begin{array}{l}(1.2) \\
(0.4)\end{array}$ & $2.3 \quad(1.7)$ & - & & - & & $3.5 \quad(8.7)$ & - & & - & 8.8 \\
\hline ARp & 0.00 & 0.03 & & 0.10 & 0.07 & & 0.04 & & 0.19 & 0.19 & & 0.09 & 0.06 \\
\hline
\end{tabular}

Criterion II (RR greater than 1.0 in all the informative studies with at least $5 \%$ of the referents exposed + at least one study statistically significant)

\begin{tabular}{|c|c|c|c|c|c|c|c|c|c|c|c|c|c|}
\hline Leather & $\infty$ & $\langle 1.0\rangle$ & 0.5 & (1.1) & $2.2(18.8)$ & 1.2 & (1.0) & $\infty$ & (1.5) & $1.2(1.0)$ & $0.5(1.3)$ & $1.8 \quad(2.9)$ & 3.8 \\
\hline engineers & 1.0 & (4.7) & 2.8 & $\langle 3.0\rangle$ & - & 2.7 & $(4.0)$ & 5.1 & (3.7) & $1.5(38.8)$ & $\begin{array}{l}1.3(4.3) \\
1.4(15.2)\end{array}$ & - & 3.1 \\
\hline Truck drivers & 1.0 & $(0.3)$ & - & & - & 2.8 & (2.3) & - & & - & $2.5(13.9)$ & $1.1(10.6)$ & 1.2 \\
\hline station & - & & - & & - & - & & - & & - & $1.2\langle 5.9)$ & $2.3 \quad(6.5)$ & - \\
\hline $\begin{array}{l}\text { Food counter } \\
\text { workers \& cooks } \\
\text { Rubberc }\end{array}$ & $=$ & & - & & $1.55(2.6)$ & $=$ & & - & & - & $1.9 \quad(4.9)$ & $1.8 \quad(7.0)$ & - \\
\hline Rubberc & - & & $\infty$ & $\{0.1\rangle$ & $1.6(13.3)$ & 5.0 & (1.0) & $\infty$ & $(0.7)$ & - & $\infty \quad(0.7)$ & $2.15(2.1)$ & $\begin{array}{l}1.2 \\
2.5\end{array}$ \\
\hline $\begin{array}{l}\text { Dyestuffc } \\
\text { Gas workersc }\end{array}$ & - & & $\begin{array}{l}\infty \\
2.4\end{array}$ & $\begin{array}{l}\langle 1.2\rangle \\
\langle 0.4\rangle\end{array}$ & $2.3(1.7)$ & $\bar{z}$ & & $\overline{-}$ & & $3.5(8.7)$ & $\overline{-}$ & $\bar{z}$ & 8.8 \\
\hline ARp & 0.01 & & 0.04 & & 0.17 & 0.05 & & 0.05 & & 0.19 & 0.18 & 0.10 & 0.07 \\
\hline
\end{tabular}

Criterion III (RR greater than 1.0 in all the informative studies with at least $5 \%$ of the referents exposed + at least two studies with a statistically significant $R R$ )

\begin{tabular}{|c|c|c|c|c|c|c|c|c|c|c|c|c|c|c|}
\hline $\begin{array}{l}\text { Machinists, } \\
\text { engineers }\end{array}$ & 1.0 & (4.7) & 2.8 & $(3.0)$ & - & 2.7 & $(4.0)$ & 5.1 & (3.7) & $1.5(38.8)$ & $\begin{array}{l}1.3(4.3) \\
1.4(15.2)\end{array}$ & - & 3.1 & (1.7) \\
\hline $\begin{array}{l}\text { Leather } \\
\text { Rubberc }\end{array}$ & $\frac{\infty}{-}$ & $(1.0)$ & $\begin{array}{l}0.5 \\
\infty\end{array}$ & $\begin{array}{l}(1.1) \\
(0.1)\end{array}$ & $\begin{array}{l}2.2(18.8) \\
1.6(13.3)\end{array}$ & $\begin{array}{l}1.2 \\
5.0\end{array}$ & $\begin{array}{l}(1.0) \\
(1.0)\end{array}$ & $\begin{array}{l}\infty \\
\infty\end{array}$ & $\begin{array}{l}(1.5) \\
(0.7)\end{array}$ & $\begin{array}{l}1.2 \\
-\end{array}$ & $\begin{array}{ll}0.5 & (1.3) \\
\infty & (0.7)\end{array}$ & $\begin{array}{ll}1.8 & (2.9) \\
2.15 & (2.1)\end{array}$ & $\begin{array}{l}3.8 \\
1.2 \\
2.5\end{array}$ & $\begin{array}{l}(2.1) \\
(2.7) \\
(2.9)\end{array}$ \\
\hline $\begin{array}{l}\text { Dyestuffc } \\
\text { Gas workers }\end{array}$ & - & & $\begin{array}{l}\infty \\
2.4\end{array}$ & $\begin{array}{l}(1.2) \\
(0.4)\end{array}$ & $\begin{array}{l}2.3(1.7) \\
-\end{array}$ & - & & - & & $\begin{array}{ll}3.5 & (8.7) \\
- & \end{array}$ & - & - & 8.8 & (2.7) \\
\hline ARp & 0.01 & & 0.04 & & 0.16 & 0.03 & & 0.05 & & 0.19 & 0.07 & 0.02 & 0.07 & \\
\hline
\end{tabular}

a Age-adjusted relative risks not available.

b Population-based case-referent studies.

c Rubber, dyestuff, and gas workers were included on the basis of evidence from cohort studies.

with one exception [postal questionnaire (23)]. Five studies mention one or more specific classifications used for coding the occupational categories; these were the Registrar's General's classification 1966 (1), the classification of the United States Bureau of the Census $(4,19,20)$, the 1971 Canadian census classification (10), and the United Nations and the International Labour Office classifications (25).

Confounding by age was controlled in all the studies, mainly by matching. Confounding by smoking was controlled in six studies, but smoking-adjusted estimates were reported only occasionally, when differing from unadjusted values. One study controlled confounding by other high-risk occupations.

Job titles and industrial activities associated with a statistically significant relative risk greater than 1.0 in at least one study are reported in table 2 .

On the basis of the occupations listed, job titles and/or industrial activities were aggregated according to the three criteria (table 3). We obtained the estimates of attributable risks by applying Miettinen's formula (12) to each job included according to each of the men- tioned criteria and summing up the job-specific attributable risks for the population within each study. The relative risks and the proportions of exposed cases on which the estimates were based are given. It is possible, however, that the same subject was engaged in more than one occupation at risk; this occurrence would result in an overestimation of the attributable risk.

As one would expect, the interstudy variability was quite large, ranging from 0 to $19 \%$ according to the first criterion and from 1 to $19 \%$ according to the other two.

The intercriterion variability was lower, being large only in the studies by Silverman et al (20) and Shoenberg et al (19), moderate in the studies by Cole et al (4) and Howe et al (10), and virtually absent in the other five studies.

\section{Discussion}

Aggregating occupations in order to estimate the attributable risk in different populations, we have used three different criteria, ranging from a less selective 
one (relative risk greater than 1.0 in all the studies, with at least one statistically significant association) to a more conservative one (at least two studies showing a statistically significant association and a relative risk greater than 1.0 in all the informative studies with at least $5 \%$ of the referents exposed).

The estimates which were generated (table 3) show variability both between and within the studies. While for most of the investigations from countries other than the United States, with the exception of that by Howe et al (10), the three criteria did not produce largely different intrastudy estimates $(1,2,23,25)$, the American investigations showed wider fluctuations.

These fluctuations could be ascribed to at least two sources of variation in the case of criterion I, ie, inclusion of occupations shared by a high proportion of the subjects $(19,20)$ or exclusion of an occupation (leather work) characterized by a high relative risk and a high prevalence in one study (4) but with inconsistencies in the reported relative risks (some of which were lower than 1.0) in other investigations.

The case of leather workers, for whom the overall epidemiologic evidence supports a causative role of the occupational exposure for cancer of the urinary tract, is a good example of the limitations of such an exercise. In fact, criterion I would not be met, even if two previously discarded studies reporting a high and statistically significant relative risk were reincluded [Schmautz \& Cole (18), relative risk 4.8 for cancer of the pelvis and ureter, and Decoufle (7), 6.3 for bladder cancer] because of the conflicting results of different studies, some with relative risks lower than 1.0. Such conflicts are resolved when only studies with at least $5 \%$ of the referents exposed are considered.

We also computed the attributable risk within a population only for those occupations with evidence of carcinogenic risk coming from cohort studies (ie, rubber, dyestuff, and gas workers). For two studies $(2,27)$ the attributable risk could not be computed, and in all the other studies the absolute frequency of each of such exposures was very low or absent. Where it could be computed, the attributable risk based on this criterion ranged from 1 to $5 \%$.

The choice of the study population does not appear to have affected grossly the variability of the attributable risk, as both in population-based and hospitalbased studies there was a wide fluctuation (table 3 ).

In principle, the lowest estimate of the attributable risk within a population should derive from the use of criterion III, which is the most conservative, while criterion I should generate the highest estimate. However, both estimates (the latter to a greater extent than the former) are likely to be affected by variability in the quality of the assessment of occupational histories. Other possible sources of inaccuracy were the following: (i) the same subject might have been engaged in more than one occupation, (ii) for a number of occupations only a few studies were informative, (iii) rare
Table 4. Power $(1-\beta)$ of the studies to detect a relative risk of 2.0 with $\alpha=0.05$ (level of statistical significance). ( $P_{0}=$ proportion of exposed referents)

\begin{tabular}{lcc}
\hline Study & $\mathrm{P}_{\mathrm{o}}=0.05$ & $\mathrm{P}_{\mathrm{o}}=0.01$ \\
\hline Wynder et al, 1963 (27) & 0.43 & 0.15 \\
Anthony \& Thomas, 1970 (1) & 0.92 & 0.31 \\
Cole et al, 1972 (4) & 0.63 & 0.17 \\
Howe et al, 1980 (10) & 0.78 & 0.23 \\
Tola et al, 1980 (23) & 0.28 & 0.08 \\
Cartwright, 1982 (2) & 0.96 & 0.40 \\
Silverman et al, 1983 (20) & 0.57 & 0.15 \\
Schoenberg et al, 1984(19) & 0.96 & 0.43 \\
Vineis \& Magnani, 1985 (25) & 0.84 & 0.27 \\
\hline
\end{tabular}

Table 5. Attributable risk in the population for smoking and bladder cancer. Men and population-based case-referent studies only were considered.

\begin{tabular}{lc}
\hline Studya & $\begin{array}{c}\text { Attributable } \\
\text { risk (\%) }\end{array}$ \\
\hline Cole et al, 1971 (6) (Boston, US) & 39 \\
Howe et al, 1980 (10) (Canada) & 61 \\
Mommsen \& Agaard 1983 (14) (Denmark) & 32 \\
Morrison et al, 1984 (15) (Manchester, UK) & 46 \\
Morrison et al, 1984 (15) (Nagoya, Japan) & 34 \\
Morrison et al, 1984 (15) (Boston, US) & 44 \\
\hline
\end{tabular}

a US = United States, UK = United Kingdom.

occupations could have been overlooked and/or their role underestimated due to the low power of many studies, and (iv) exposure to bladder carcinogens for workers sharing the same occupation is likely to have been unequal. The last possibility is expressed by variations in the estimates of the relative risks in the same occupation among different studies. The third point can be particularly relevant. Table 4 , in fact, shows the limitations of many studies with respect to statistical power, expecially for a low proportion of exposed referents ( $1 \%$ or less).

In spite of the described limitations and the fact that each estimate should always be regarded as place- and time-specific, this exercise suggests that the attributable risk within a population can be used as a good, albeit imprecise, epidemiologic measure of the cancer burden which can be prevented by the removal of occupational exposure to carcinogenic factors. In fact, the application of three different criteria for the inclusion of occupations does not result, for most of the studies, in a wide variation in the attributable risk.

There are at least two possible explanations for this stability: (i) the differences between the criteria applied were not large enough to detect wide variations or (ii) the product of the magnitude of the risk by the size of the occupational population exposed tends to be approximately constant within the same study in different occupational groups.

The inclusion of further studies or a duplication of the same analysis with other site-specific data sets are warranted to clarify the issue.

For comparison, table 5 reports the attributable risk for smoking and bladder cancer among men, as esti- 
mated by the authors of the available population-based case-referent studies. The lower variability of the estimates among studies may be attributed to the higher and more stable proportion of smokers in different western populations, in comparison with specific occupational exposures.

\section{Acknowledgments}

We are indebted to B Terracini, University of Turin, Italy, and to AC Fletcher, International Agency for Research on Cancer, Lyon, France, for their useful comments.

\section{References}

1. Anthony HM, Thomas GM. Tumors of the urinary bladder: An analysis of the occupations of 1,030 patients in Leeds, England. J Natl Cancer Inst 45 (1970) 879-895.

2. Cartwright R. Occupational bladder cancer and cigarette smoking in West Yorkshire. Scand J Work Environ Health 8 (1982): suppl 1, 79-82.

3. Coggon D, Pannet B, Acheson ED. Use of job-exposure matrix in an occupational analysis of lung and bladder cancers on the basis of death certificates. $J$ Natl Cancer Inst 72 (1984): 2, 61-65.

4. Cole P, Hoover R, Friedell GH. Occupation and cancer of the lower urinary tract. Cancer 29 (1972) $1250-1260$.

5. Cole P, Merletti F. Chemical agents and occupational cancer. J Environ Path Toxicol 3 (1980) 399-417.

6. Cole P, Monson RR, Harring H, Friedell GH. Smoking and cancer of the lower urinary tract. N Engl J Med 284 (1971) 129-134.

7. Decoufle P. Cancer risks associated with employment in the leather and leather products industry. Arch Environ Health 34 (1979) 33-37.

8. Decoufle P, Stanislawczyk K, Houten L, Bross ID, Viadana $\mathrm{E}$. A retrospective survey of cancer in relation to occupation. US Government Printing Office, Washington, DC 1977. (DHEW publication no 77-178).

9. Dunham LJ, Rabson AS, Stewart HL, Frank AS, Young JL. Rates, interview, and pathology study of cancer of the urinary bladder in New Orleans, Louisiana. J Natl Cancer Inst 41 (1968) 683-709.

10. Howe GR, Burch JD, Miller AB, Cook GM, Esteve J, Morrison B, Gordon P, Chambers LW, Fodor G, Winsor GM. Tobacco use, occupation, coffee, various nutrients and bladder cancer. J Natl Cancer Inst 64 (1980): 4, 701-713.

11. Merletti F, Heseltine E, Saracci R, Vainio H, Wilbourn
J. Target organs for carcinogenicity of chemicals and industrial exposures in humans: A review of results in the IARC Monographs on the Evaluation of the Carcinogenic Risks of Chemicals to Humans. Cancer Res 44 (1984) 2244-2250.

12. Miettinen OS. Estimability and estimation in casereferent studies. Am J Epidemiol 103 (1976) 226-235.

13. Milham S Jr. Occupational mortality in Washington State 1950-1979. National Institute for Occupational Safety and Health, Cincinnati, OH 1983.

14. Mommsen S, Ågard J. Tobacco as a risk factor in bladder cancer. Carcinogenesis 4 (1983) 335-338.

15. Morrison AS, Buring JE, Verhoek WG, Aoki K, Leck I, Ohno Y, Obata K. An international study of smoking and bladder cancer. J Urol 131 (1984) 650-654.

16. Najem GR, Louria DB, Seebode JJ, Thind IS, Prusakowski JM, Ambrose RB, Fernicola AR. Life time occupation, smoking, caffeine, saccharine, hair dyes and bladder carcinogenesis. Int J Epidemiol 11 (1982) $212-217$.

17. Office of Population Censuses and Surveys. Occupational mortality 1970-72. Her Majesty's Stationery Office, London 1978.

18. Schmautz R, Cole P. Epidemiology of cancer of the renal pelvis and ureter. J Natl Cancer Inst 52 (1974): 5, $1431-1434$.

19. Schoenberg JB, Stemhagen A, Mogielnicki AP, Altman R, Toshi A, Mason TJ. Case-control study of bladder cancer in New Jersey: I Occupational exposures in white males. J Natl Cancer Inst 72 (1984): 5, 973-981.

20. Silverman DT, Hoover RN, Albert S, Graff KM. Occupation and cancer of the lower urinary tract in Detroit. J Natl Cancer Inst 70 (1983): 2, 237-245.

21. Simonato L, Saracci R. Cancer, occupational. In: Parmeggiani L, ed. Encyclopaedia of occupational health and safety, International Labour Office, Geneva 1983, pp 369-375.

22. Sullivan JW. Epidemiological survey of bladder cancer in Greater New Orleans. J Urol 128 (1982) 281-283.

23. Tola S, Tenho M, Korkala ML, Järvinen E. Cancer of the urinary bladder in Finland. Int Arch Occup Environ Health 46 (1980) 43-51.

24. Tyrrel AB, MacAirt JG, McCaughey WT. Occupational and non-occupational factors associated with vesical neoplasm in Ireland. J Ir Med Assoc 64 (1971) 213-217.

25. Vineis $\mathbf{P}$, Magnani $\mathbf{C}$. Bladder cancer and occupation in males: A case-control study. Int J Cancer 35 (1985) 599-607.

26. Wynder EL, Goldsmith R. The epidemiology of bladder cancer: A second look. Cancer 40 (1977) 1246-1268.

27. Wynder EL, Onderdonk J, Mantel N. An epidemiological investigation of cancer of the bladder. Cancer 16 (1963) $1388-1407$.

Received for publication 4 July 1985 